\title{
Analysis of the Factors Affecting Canalith Repositioning Maneuver Treatment of in Posterior Canal Benign Paroxysmal Positional Vertigo of a Dizziness Patient
}

\author{
Chul-Seung Kim
}

Department of Clinical Laboratory Science, Mokpo Science University, Mokpo, Korea

\section{뒤반고리관 양성발작성 두위현기증 어지럼증 환자 이석정복술 치료에 영향을 주는 인자 분석}

\author{
김철승 \\ 목포과학대학교 임상병리과
}

\begin{abstract}
Posterior canal benign paroxysmal positional vertigo (PCBPPV) is the most common disease among patients who visited the st. Carollo hospital dizziness center with the head suddenly feeling rolling or rotational dizziness caused by head and body movements. Most patients showed improvements in symptoms after a single treatment. On the other hand, there are more causes requiring multiple treatments. This study examined the factors affecting the canalithiasis repositioning maneuver for symptom recovery of dizziness, which is posterior BPPV. Dizziness patients who visited the dizziness center of PCBPPV were classified. From March 2008 to November 2010, the cure rate of 165 posterior BPPVs patients was investigated. The success rate after the first, second, third, and further treatments was $57.6 \%, 17.6 \%, 10.3 \%$, and $14.5 \%$, respectively. The factors affecting treatment of PCBPPVs included traumatic, medical disease, cerebral infarction, small vessel disease, vestbro basilar artery insufficiency (VBI), cerebrovascular disease, brain disease, and vestibuloplasty $(P<0.05)$. Vomiting, nausea, and syncope can be treated easily by considering the factors affecting these treatments. If the related diseases are combined with the treatment of the canalithiasis repositioning maneuver for symptom recovery of dizziness, the results will show an improvement in daily life that is free from painful dizziness.
\end{abstract}

Key words: Canalith repositioning maneuver, Posterior canal benign paroxysmal vertigo, Post-traumatic, Vestbro basilar artery insufficiency, Vestibulopathy

This is an Open Access article distributed under the terms of the Creative Commons Attribution Non-Commercial License (http://creativecommons.org/licenses/by-nc/4.0) which permits unrestricted non-commercial use, distribution, and reproduction in any medium, provided the original work is properly cited.

Copyright () 2018 The Korean Society for Clinical Laboratory Science. All rights reserved.
Corresponding author: Chul-Seung Kim Department of Clinical Laboratory Science, Mokpo Science University, 413-1 Yeongsan-ro, Mokpo 58644, Korea Tel: 82-61-270-2732 Fax: 82-61-279-8838 E-mail: hippo48@hanmail.net

Received: August 13, 2018 Revised $1^{\text {st. }}$ : August 28, 2018 Revised $2^{\text {nd }}$ : August 30, 2018 Accepted: August 30, 2018

\section{서 론}

뒤반고리관 양성발작성두위현기증(posterior canal benign paroxysmal positional vertigo, PCBPPV)은 어지럼중 가장 흔한 질환으로 팽대부릉이 정상적인 상태에서 내임파액과 동일 한 중력을 기 때문에 회전가속도에서만 반응하던 반고리관이
생리학적 변화를 일으켜 팽대부릉과 내임파액의 중력의 차이가 발생하여 선형가속도에서 반응하게 된 병적 상태를 말한다[1]. 흔히 일상 생활하는 도중 빙빙 도는 느낌, 오심, 구토 등의 어지 럼증을 호소하는 환자들이 많은데 대부분 빈혈, 기립성저혈압, 뇌질환이라고 생각하고 약물치료만 계속하면서 어지럼증을 계 속 호소하는 경우가 있다. 
귀쪽에 존재하는 이석이라는 소금덩어리가 반고리관내에 들 어가 평형반이 약화되어 어지럼증을 나타나는 경우가 흔하다. 이러한 대표적인 질환이 PCBPPV로서 환자들은 잠자리에 눕거 나 일어날 때, 선반에서 물건을 꺼내려고 올려볼 때, 몸을 앞으 로 구부릴때 지속시간이 30초 이내 또는 수분이상 지속적으로 어지럼증을 호소한다. 회전성 어지럼증 이외에 많은 환자들이 쓰러질 것 같은 느낌, 떠다니는 느낌, 구역질나는 느낌, 머리움 직임에 대한 공포를 호소한다[2]. 위와같은 증상을 호소하는 환 자에 대하여 Dix-Hallpike검사로 뒤반고리관형 양성발작성 두 위현기증 진단 후 Figure 1 과 같은 애플리 이석정복술(epley maneuver, EM)을 시행하였다[3].

국내 보고에 따르면 변형된 $\mathrm{EM}$ 을 통하여 96 100\%의 치료 율을 보고하고 있으며 [4, 5], 그 외에도 많은 연구에서 이석 치환 술의 효과를 입증한 바 있다. 치료를 끝내는 시점은 검사에 의한 눈떨림 및 어지럼 증세가 완전히 사라졌을 때이다[6]. 이후항 어 지럼 약물 투여군, 이석 치환술만 행한 군과약물 투여와 이석 치
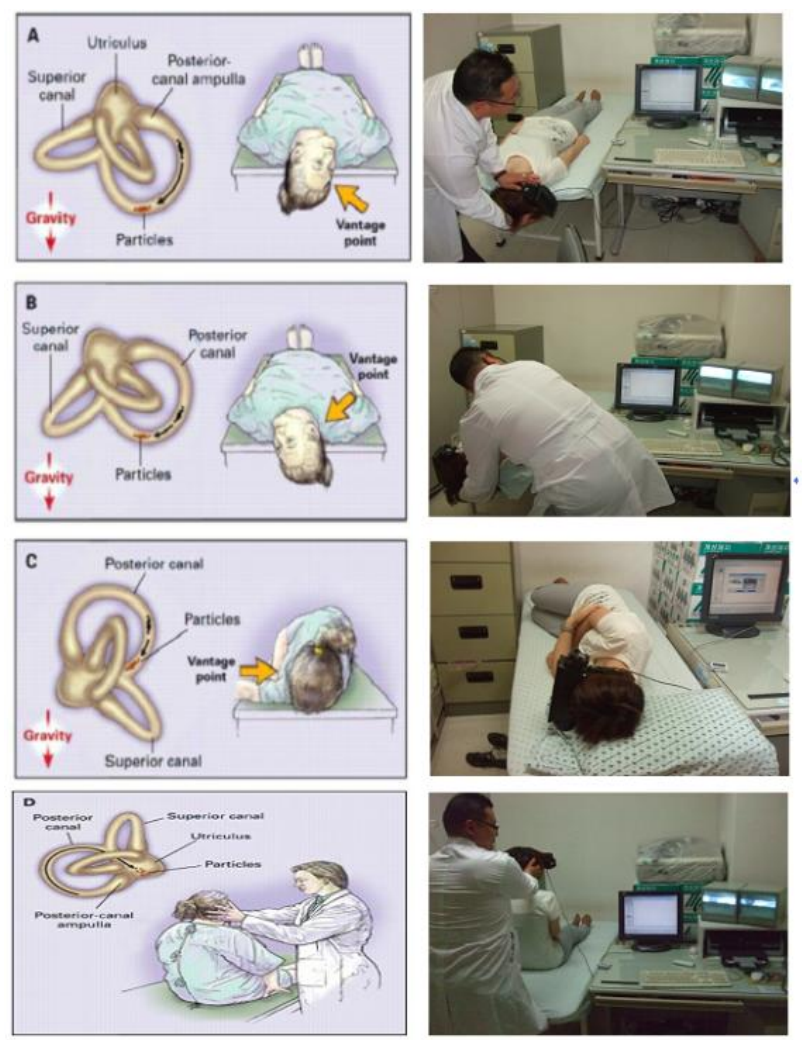

Figure 1. Epley maneuver (right ear). The patient is seated on a table as viewed from the right side. (A) Patient in norma Dix-Hallpike head-hanging position, then rotated toward the opposite side with the neck in full extension through position (B) and into position $(C)$ in a steady motion by rolling the patient onto the opposite lateral side and then the patient sits back up to position (D) [3].
환술을 동시에 행한 군을 비교한 연구에서 이석치환술군과 약 물과 치환술을 동시에 행한 군이 약물만 투여한 군보다 유의성 있게 치료율이 더 좋았으며 치환술만 행한 군과 약물과 치환술 을 동시에 행한 군 사이에는 치료율의 차이에 유의성이 없었다 는 보고가 있다[7].

대부분 양성발작성 두위현기증에 의한 어지럼증 환자들은 어지럼증에 의한 극심한 공포와 제대로 된 일상생활을 영위할 수 없을 정도로 어지럼증을 호소한다. 양성발작성두위현기증 에 의한 어지럼증으로 진단될 경우 간단한 치료방법으로 바로 어지럼증에서 벗어날 수 있지만, 계속 재발할 경우가 있고 반고 리관별로 재발하는 원인들이 다양하다. 이에 치료후에도 어지 럼증을 재발되는 원인 분석을 통해 치료예후인자를 고려한 치 료를 통해 많은 어지럼증 환자의 치료에 도움을 줄수 있을 것이다.

\section{재료 및 방법}

\section{1. 검사 및 진단방법}

2008년 3월부터 2010년 11월까지 전남 순천성가롤로병원 어지럼증 센터 내원한 어지럼증 환자에게 비디오눈떨림검사를 통해 진단된 PCBPPV 환자 165 명을 대상으로 치료 횟수와 양성 발작성 두위현기증과 동반된 질환에 의한 어지럼증 지속여부 상관성을 분석하였다. PCBPPV진단을 위해 Dix- Hallpike 검 사를 시행하였고 검사 전에 환자에게 심한 어지럼이 발생할 수 있음을 설명하고 검사 중에는 되도록 중앙을 응시한 채 눈을 뜬 상태를 유지하게 하였다. 검사는 앉은 자세에서 환자의 머리를 병변 쪽으로 $45^{\circ}$ 돌린 상태로 환자를 눕히고 머리를 뒤로 $20^{\circ}$ 정 도 낮게 유지한 후 눈떨림을 관찰한다. 뒤반고리관 환자에서 Dix-Hallpike 검사 시 유발되어 나타나는 눈떨림의 특징은 잠 복기는 대부분 2 20초 정도이나 드물게는 1 분정도 걸리는 경 우도 있어 눈떨림이 나타날 때까지 자세를 유지하고 관찰하는 것이 좋다. 눈떨림의 방향은 상향이고 눈동자의 최첨부가 바닥 으로 향하는 회전 양상의 혼합성 눈떨림이 관찰된다. 또한 눈떨 림의 강도는 시작은 약하게 점차강도가 증가하다 다시 약해지 며 사라지는 눈떨림이 특징이다. 눈떨림이 발생하면 환자는 주 관적인 어지럼을 느끼게 된다. 일어나 앉을 때 반대방향의 눈떨 림의 역전과 어지럼증이 흔하게 동반되고, 몸 변환 검사가 반복 될 시 눈떨림의 강도가 약해지고 결국은 관찰되지 않는 피로현 상이 관찰된다(Figure 2) [8].

또한 몸이나 머리의 위치를 변환시켜서 반고리관내에 존재 하는 이석이 평형반을 흥분시켜 눈 주위의 근육을 자극하여 특 이한 눈떨림을 감지하기 위하여 프렌즈 안경을 착용하게 하였 


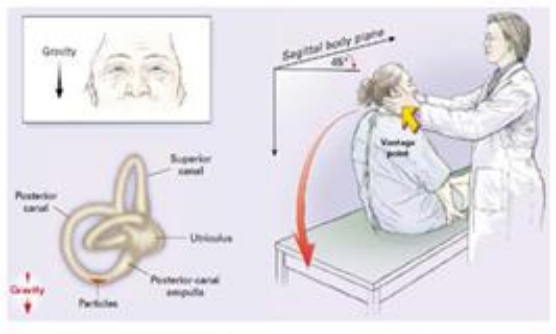

(A)
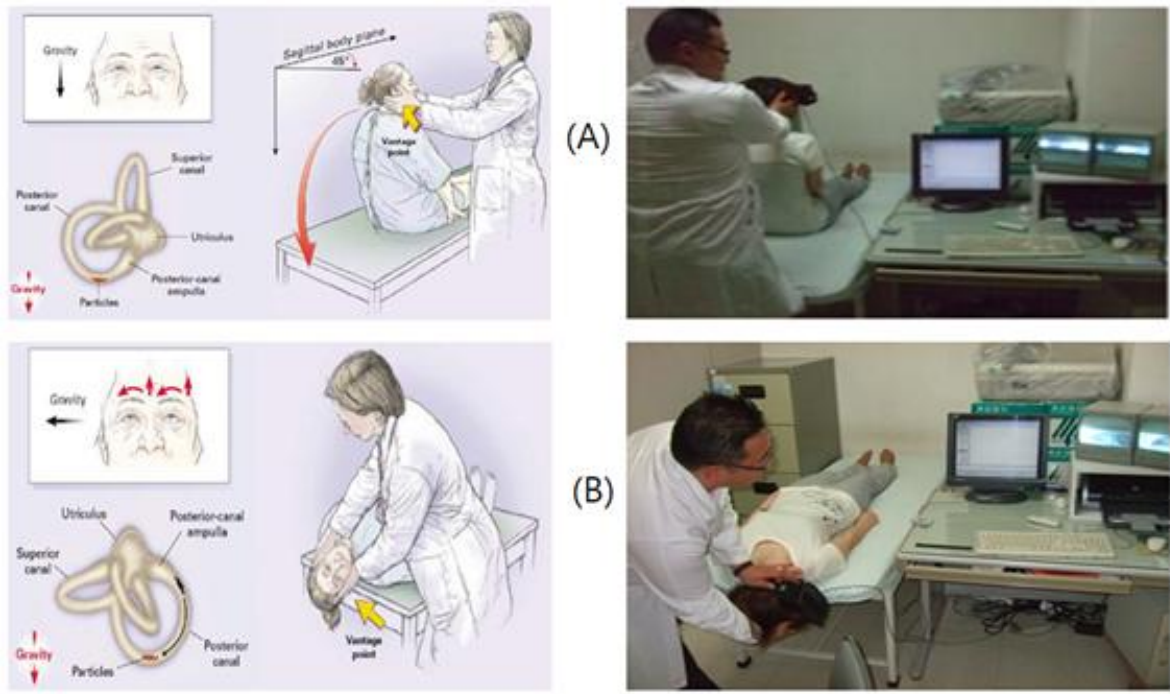

(B)

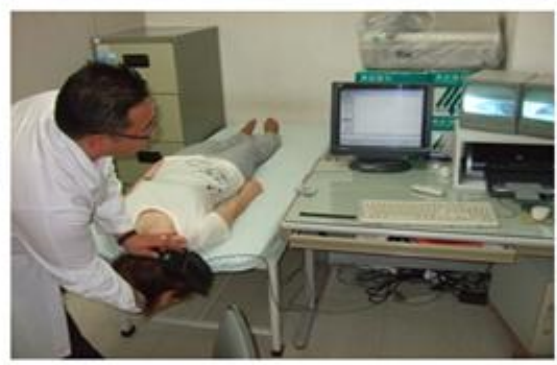

Figure 2. Dix-Hallpike maneuver (right ear). The patient is seated and positioned so that the patient's head will extend over the top edge of the table when supine. The head is turned $45^{\circ}$ toward the ear being tested (position A). The patient is quickly lowered into the supine position with the head extending about $30^{\circ}$ below the horizontal (position B). The patient head is held in this position and the examiner observes the patient eyes for nystagmus [2, 8].

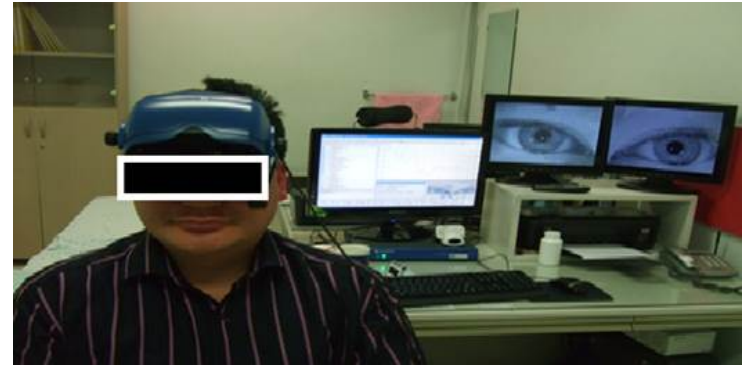

Figure 3. Video nystagmus test. nystagmus detect the eyes movement by wearing french goggles, the front of sensor to detect and monitor the location of the vertical and horizontal position of the eyes to detect movement up, down, left and the side is represented by display in graphy.

고, 고글 앞쪽의 센서가 눈동자의 위치를 감지하고 두위의 변환 시 어지럼이 유발되는 병력의 환자가 특징적인 눈떨림이 유발 되고, 수직 수평으로 눈동자의 위치를 감지하여 좌우상하로 움 직이는 눈떨림을 그래프로 기록될 시, 뒤반고리관 양성발작성 두위현기증을 진단하였다(Figure 3) [5].

연구에 참여한 모든 대상자의 선정에 윤리적인 절차를 거쳐 연구자가 직접 연구의 목적을 설명하고 연구방법 및 참여기간, 부작용 및 위험요소, 개인정보와 비밀보장, 중도탈퇴 할 수 있음 에 대한 내용을 공지하고 각각의 서면 사전 동의를 얻어 연구를 수행하였다. 비디오 눈떨림 검사장비로 검사를 통하여 뒤반고 리관형 양성발작성두위현기증을 진단하였다.

\section{2. 치료방법}

PCBPPV로 진단된 경우 EM을 시행하였고(Figure 1), 어지 럼증 치료약물을 처방하였다. $\mathrm{EM}$ 을 시행할 때 앉은 자세에서
병변쪽으로 Dix-Hallpike자세를 취한 후 눈떨림을 관찰한다. 이후 천천히 머리를 반대쪽으로 $90^{\circ}$ 돌리고, 고개는 최대한 신 전된 상태를 유지한다. 이어서 몸 전체와 머리를 $90^{\circ}$ 반대쪽으 로 누운 다음, 바로 앉은 자세를 유지한 채 눈떨림을 확인하다. 이 때 관찰되는 눈떨림이 초기 Dix-Hallpike시와 동일하다면, 이석이 공통각을 통하여 타원주머니로 가고 있음을 유추할 수 있고 치료가 성공적임을 추정할 수 있다. 보통, 각 단계별로 자 세를 $1 \sim 2$ 분정도 유지하거나, 눈떨림이 사라지는 시점까지 자 세를 유지 시켜야 하고, 한 번의 치료가 5 분 정도의 시간이 걸리 며, 치료 후 24 48시간 동안 눕지 않을 것을 환자에게 주지 시 켜야 한다(Figure 1) [2, 8]. 이석정복술 후 다음날부터는 정상적 인 생활을 하도록 하였다. 환자는 2일에서 1 2주후에 다시 내 원하여 어지럼증의 주관적 증상이 있는지 여부를 확인하여 비 디오 눈떨림 검사를 통해 눈떨림 유무를 확인하였다. 특징적인 눈떨림이 소실한 경우를 치료성공으로 보았다. 만약 주관적 어 지럼증이 존재하고 비디오 눈떨림 검사를 통해 눈떨림이 남아 있는 경우는 다시 이석정복술을 시행하였고, 다시 어지럼증이 발생할 경우 방문하도록 하였다. 입원환자의 경우 매일 어지럼 증유무를 체크하여 눈떨림이 소실 될 때까지 이석정복술을 시 행하였다. 어지럼증센터에 내원할 때 마다 비디오 눈떨림 검사 장비로 눈떨림 유무를 판정하여 치료횟수를 산정하였다.

\section{3. 관찰항목}

임상양상 분석은 $\mathrm{PCBPPV}$ 의 치료성적분석, 이석정복술 후 치료 실패요인에 대한 분석을 시행하였다. 관련 예후 인자별로 외상유무, 뇌 쪽 질환유무, 메니에르 및 두통, 편두통, 중이염, 안 뜰신경염, 당뇨, 고혈압의 유무 등을 조사하였고, 치료전 증상의 
지속시간-치료성적에 미치는 영향을 통계적 분석인 SPSS version 18.0, SPSS Inc., Chicago, IL, USA를 이용하여 기술통계량 (descriptive statistics)에서 교차분석(cross table)을 통해 람 다 $(\lambda)$ 값을 통해 근사유의확률을 구했다. 근사유의확률은 $P<$ 0.05 미만일 경우 통계적으로 유의하다고 판정하였다.

\section{결 과}

뒤반고리관 양성발작성두위현기증을 일으키는 원인인자에 대하여 살펴보면 원인이 미상인 경우가 79례(47.9\%), 머리 등 외상 후 20례(12.1\%), 고혈압, 당뇨, 신부전등 내과적인 질환을 동반한 경우가 12 례(7.3\%), 이명 4례(2.4\%), 청력소실, 중이염, 편두통, 두통, 연령이 증가할수록 뇌혈관의 직경이 조금씩 줄어

Table 1. Factors analysis affecting treatment of posterior canal benign paroxysmal positional vertigo $(\mathrm{N}=165)$

\begin{tabular}{|c|c|c|c|}
\hline \multirow{2}{*}{ Diagnosis Positional } & \multicolumn{3}{|c|}{ Treatment visits/No. of patients (\%) } \\
\hline & Rt PCBPPV & Lt PCBPPV & Total $(\%)$ \\
\hline Idiopathic & $40(24.2)$ & $39(23.6)$ & $79(47.9)$ \\
\hline Post $\sim$ traumatic & $13(7.9)$ & $7(4.2)$ & $20(12.1)$ \\
\hline Medicine disease & $8(4.8)$ & $4(2.4)$ & $12(7.3)$ \\
\hline Tinnitus & $2(1.2)$ & $2(1.2)$ & $4(2.4)$ \\
\hline Hearing loss & $1(0.6)$ & $1(0.6)$ & $2(1.2)$ \\
\hline Otitis media & $1(0.6)$ & $1(0.6)$ & $2(1.2)$ \\
\hline Migraine & $2(1.2)$ & 0 & $2(1.2)$ \\
\hline Headache & $1(0.6)$ & $1(0.6)$ & $2(1.2)$ \\
\hline Small vessle & $4(2.4)$ & $2(1.2)$ & $6(3.6)$ \\
\hline Cerebral infarction & $5(3.0)$ & $2(1.2)$ & $7(4.2)$ \\
\hline VBI & $1(0.6)$ & $2(1.2)$ & $3(1.8)$ \\
\hline $\begin{array}{l}\text { Cerebral vessel } \\
\text { disease }\end{array}$ & $1(0.6)$ & $3(1.8)$ & $4(2.4)$ \\
\hline Brain disease & $4(2.4)$ & 0 & $4(2.4)$ \\
\hline Vestibulopathy & $7(4.2)$ & $3(1.8)$ & $10(6.1)$ \\
\hline $\begin{array}{l}\text { Transient cerebral } \\
\text { ischemia }\end{array}$ & $1(0.6)$ & $1(0.6)$ & $2(1.2)$ \\
\hline Others & $5(0.6)$ & $1(0.6)$ & $6(3.6)$ \\
\hline Total & $96(58.2)$ & $67(41.8)$ & $165(100)$ \\
\hline
\end{tabular}

The values are $\mathrm{N}(\%)$.

Abbreviations: PCBPPV, posterior canal benign paroxysmal positional vertigo; VBI, vertebro basilar artery Insufficiency.
드는 환자 2례(1.2\%), 뇌혈관 직경이 좁아진 환자 6례(3.6\%), 뇌 경색 7례(4.2\%), 뇌혈관 질환, 뇌손상 4례(2.4\%), 안뜰신경염 10 례(6.1\%), 척추뇌바닥동맥 기능부전증 3례(1.8\%)등 귀와 관 련된 질환 및 중추성질환등에 의해 유발되었다(Table 1).

PCBPPV 165명 환자를 대상으로 EM 치료 횟수를 측정하였 다. 1회 치료 성공률이 $57.6 \%$ 로 높은 수치를 보였고, 2회 치료 성공률이 $17.6 \%, 3$ 회 치료 성공률이 $10.3 \%, 3$ 회 이상 치료 성공 률이 $14.5 \%$ 로 조사되었다. 오른쪽이 치료 성공률이 약간 높았 다(Table 2).

PCBPPV EM 치료횟수에 영향을 주는 인자들을 분석해보면 1 회 성공률은 원인불명 $47.8 \%$ 으로 유의적으로 가장 높았고, small vessel, 뇌경색, 안뜰신경염을 동반하면 치료율이 현저히 떨어졌다. 그리고 3 회 이상의 어지럼증이 지속된 경우가 원인불 명, 외상 후, 뇌경색, 척추뇌바닥동맥기능부전증(vertebro basilar artery insufficiency, VBI), 뇌혈관질환(척추동맥 좁아짐 등), 안뜰신경염 등이 있었다. 통계적으로 원인불명, 외상 후, 내과적 질환, 뇌경색, $\mathrm{VBI}$, 뇌혈관질환, 뇌질환, 안뜰신경염 등이 치료 횟수와 상관성을 보였다 $(P<0.05)$ (Table 3$)$.

주로 안뜰계와 관련된 부분의 질환에 의해 반고리관의 기능 약화로 이석이 발생한 것으로 보인다. 뇌경색 경우 중대뇌동맥 협착으로 인해 반고리관으로 혈류량이 감소하여 반고리관의 기 능이 약화되고, 안뜰신경염인 경우에는 평형을 담당하는 기관 인 안뜰기관의 반고리관에 염증을 동반할 수 있고 이석치료가 되더라도 안뜰신경염을 치료하지 않으면 계속적으로 어지럼증 을 동반할 수 있다.

중추성 질환을 통한 어지럼증을 판단하기 위하여 뇌혈관 자 기공명영상(magnetic resonance angiography, MRA)를 통해 척추뇌바닥동맥(veterbro-basilar artery, $\mathrm{VA}$ )의 기형을 살펴 본 결과 척추동맥 또는 뇌바닥동맥의 기형에 의해 양성발작성 두위현기증이 나타났다. 특히 척추동맥의 기형에 의한 폐쇄나 협착은 숨뇌에 영향을 미칠 수 있기 때문에 어지럼증과 밀접한 관련성이 있다.

Figure 3은 정상적인 MRA소견이고 Figure 4는 척추동맥이

Table 2. Location of disease and number of treatment $(N=165)$

\begin{tabular}{lcccccc}
\hline \multirow{2}{*}{ Positional } & \multicolumn{7}{c}{ Treatment visits/No. of patients (\%) } \\
\cline { 2 - 7 } & 1 & 2 & 3 & $>3$ & Total & $P$-value \\
\hline Rt PCBPPV & $51(53.7)$ & $21(72.4)$ & $11(64.7)$ & $13(54.2)$ & $96(58.2)$ & 0.015 \\
Lt PCBPPV & $44(46.3)$ & $8(27.6)$ & $6(35.3)$ & $11(45.8)$ & $69(41.8)$ & 0.018 \\
Total & $95(57.6)$ & $29(17.6)$ & $17(10.3)$ & $24(14.5)$ & $165(100)$ & 0.009 \\
\hline
\end{tabular}

The values are $\mathrm{N}(\%)$

Abbreviation: PCBPPV, Posterior canal benign paroxysmal positional vertigo. 
Table 3. Treatments ratio of posterior canal benign paroxysmal positional vertigo $(N=165)$

\begin{tabular}{|c|c|c|c|c|c|c|}
\hline \multirow{2}{*}{ Diagnosis } & \multicolumn{4}{|c|}{ Treatment visits/No. of patients (\%) } & \multirow{2}{*}{ Total (\%) } & \multirow{2}{*}{$P$-value } \\
\hline & 1 & 2 & 3 & $>3$ & & \\
\hline Idiopathic & $64(38.8)$ & $5(3.0)$ & $3(1.8)$ & $7(4.2)$ & $79(47.88)$ & 0.008 \\
\hline Post $\sim$ traumatic & $14(8.5)$ & $1(0.6)$ & $2(1.2)$ & $3(1.8)$ & $20(12.12)$ & 0.014 \\
\hline Medicine disease & $7(4.2)$ & $4(2.4)$ & 0 & $1(0.6)$ & $12(7.27)$ & 0.012 \\
\hline Tinnitus & $1(0.6)$ & $1(0.6)$ & $1(0.6)$ & $1(0.6)$ & $4(2.42)$ & 0.128 \\
\hline Hearing loss & $1(0.6)$ & $1(0.6)$ & 0 & 0 & $2(1.21)$ & 0.074 \\
\hline Otitis media & 0 & 0 & $1(0.6)$ & $1(0.6)$ & $2(1.21)$ & 0.074 \\
\hline Migraine & 0 & 0 & $1(0.6)$ & $1(0.6)$ & $2(1.21)$ & 0.074 \\
\hline Headache & $1(0.6)$ & $1(0.6)$ & 0 & 0 & $2(1.21)$ & 0.074 \\
\hline Small vessel disease & $1(0.6)$ & $3(1.8)$ & $1(0.6)$ & $1(0.6)$ & $6(3.65)$ & 0.062 \\
\hline Cerebral infarction & $1(0.6)$ & $1(0.6)$ & $2(1.2)$ & $3(1.8)$ & $7(4.24)$ & 0.028 \\
\hline VBI & 0 & $2(1.2)$ & 0 & $1(0.6)$ & $3(1.82)$ & 0.036 \\
\hline Cerebrovascular disease & 0 & $1(0.6)$ & $2(1.2)$ & $1(0.6)$ & $4(2.42)$ & 0.036 \\
\hline Brain disease & $2(1.2)$ & $1(0.6)$ & $1(0.6)$ & 0 & $4(2.42)$ & 0.029 \\
\hline Vestibulopathy & $1(0.6)$ & $5(3.0)$ & $1(0.6)$ & $3(1.8)$ & $10(6.06)$ & 0.026 \\
\hline Transient cerebral ischemia & $1(0.6)$ & $1(0.6)$ & 0 & 0 & $2(1.21)$ & 0.074 \\
\hline Others & $1(0.6)$ & $3(1.8)$ & $2(1.2)$ & 0 & $6(3.65)$ & 0.012 \\
\hline Total & $94(57.6)$ & $29(17.6)$ & $17(10.3)$ & $24(14.5)$ & 159 (100) & 0.009 \\
\hline
\end{tabular}

The values are $\mathrm{N}(\%)$.

Abbreviation: $\mathrm{VBI}$, vertebro basilar artery insufficiency.

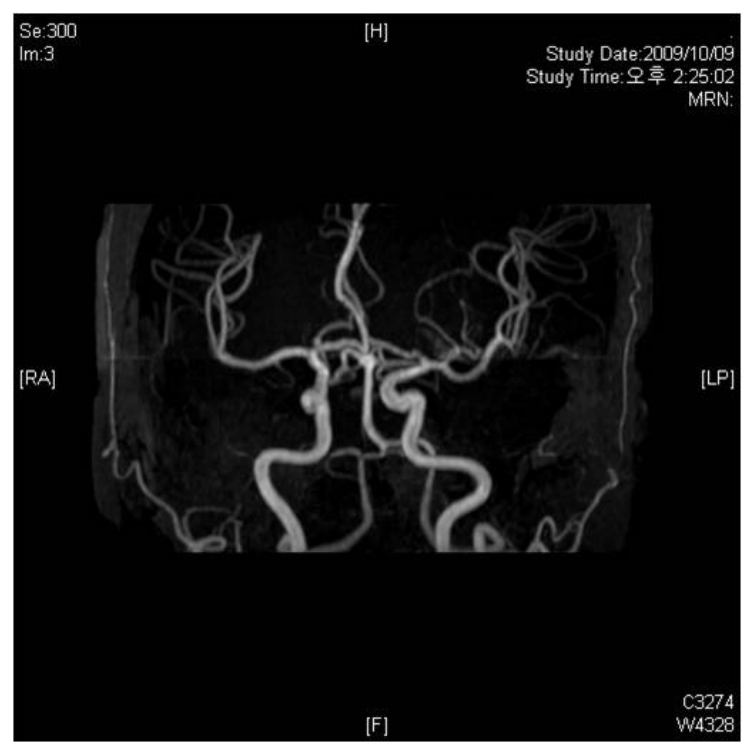

Figure 4. Normal study of MRA angiography.

Abbreviation: MRA, Magnetic resonance angiography.

정상축에서 $3 \mathrm{~mm}$ 정도 굴곡된 소견이다. 이 환자의 경우 2009 년 9월에 내원하여 빙빙 도는 느낌과 구토를 동반한 현기증을 호소하여 비디오 눈떨림 검사결과 오른쪽 뒤반고리관 양성발작 성 현기증으로 진단되었고, 이석 정복술로 치료하였으나, 계속 적으로 어지럼증을 호소하여 뇌혈관촬영 결과 척추동맥의 기형 으로 뇌혈류의 안뜰기관 유입에 장애를 가져와 안뜰신경염을 일으켰고 이후 양성발작성 두위현기증을 유발하였다. 이석정 복술 2회 이후 이석치료는 되었으나 어지럼증이 지속되어 계속
적인 약물 치료가 필요했다.

\section{고 찰}

PCBPPV는 가쪽반고리관 양성발작성두위현기증(lateral canal benign paroxymal positional vertogo, LCBPPV)과 비 슷하게 어지럼증을 일으키는 질환 중 가장 흔하다[9]. PCBPPV 는 잠자리에 눕거나 일어날 때, 선반에서 물건을 꺼내려고 올려 볼 때, 몸을 앞으로 구부릴 때 지속시간이 30초 이내 또는 수분 이상 지속적인 회전성어지럼증을 유발하고, 쓰러질 것 같은 느 낌, 떠다니는 느낌, 구역질나는 느낌, 머리 움직임에 대한 공포 를 호소한다[2]. 반면, LCBPPV은 갑자기 일어나거나, 옆으로 누울 때 빙빙 돌면서 오심이 나타나고 심하면 구토를 동반하는 경우가 있다. 이와 같이 증상별 반고리관내 이석유입 부위가 다 르기 때문에 적절한 이석정복술의 선택이 필수적이다. 이러한 점을 고려하여 정확한 임상진단과정이 필요하고, 자세한 문진 을 통해 특징적인 소견이 나타나는지를 알아본 후 눈떨림의 관 찰을 통한 이석위치를 확인하는 것이 선행되어야 할 것이다[1].

$\mathrm{PCBPPV}$ 가 진단되면 이석이 반고리관 또는 팽대부릉정을 자 극하여 평형 리듬이 깨지면서 어지럼증이 유발될 수 있고 이석 을 제거하면 다시 평형의 리듬이 돌아오게 된다. 이석정복술 방 법은 LCBPPV 치료 방법인 바비큐법(Barbecue methode)과 달리[3, 6, 9], EM법을 시행한다[3, 6, 8]. 이 때 관찰되는 눈떨림 이 초기 Dix-Hallpike시와 동일하다면, 이석이 공통각을 통하 

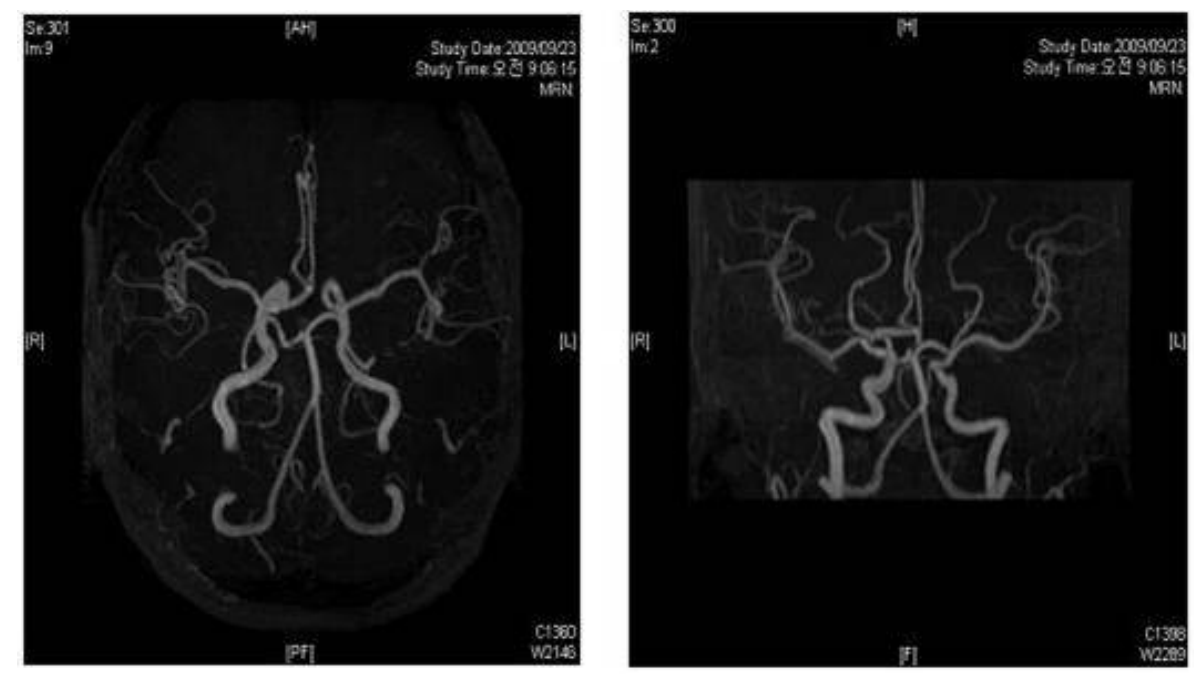

Figure 5. BA abnormality in MRA. Deviation over twice the length of BA diameter from an imaginary line. About $3 \mathrm{~mm}$ aneurysm at basilar tip. Abbreviations: BA, basilar artery; MRA, Magnetic resonance angiography.
여 타원주머니로 가고 있음을 유추할 수 있고 치료가 성공적임 을 추정할 수 있다[3]. 이러한 이석정복술을 통해 이석이 제거되 면 치료 즉시 어지럼증이 호전되지만, PCBPPV 유발시키는 인 자들에 의해 이석정복술 치료횟수가 증가 될 수 있다. 이석정복 술의 결과에 영향을 주는 연구 보고는 많지 않다. 양성발작성두 위현기증 환자에서 효과적인 치료법으로 이석정복술이 이용되 고 있으며, 이석정복술의 1 회 치료로 실패한 경우는 $12 \%$ 에서 $56 \%$ 로 보고되고 있다[10, 11]. 본 연구결과 $57.6 \%$ 의 어지럼증 환자가 1회 이석정복술로 어지럼증이 호전되었다(Table 2). 다 른 보고와 유사한 성공률을 보이였다[10, 11]. BPPV 중 PCBPPV 을 진단받은 165 명의 환자를 대상으로 $\mathrm{EM}$ 을 시행한 결과 1 회 치료로 회복된 경우가 $57.6 \%$ 로 높은 수치를 보였고 2회 치료로 회복된 경우가 $17.6 \%, 3$ 회 치료로 회복된 경우가 $10.3 \%, 3$ 회 이 상 치료로 회복되거나 계속 지속된 경우가 $14.5 \%$ 이었다(Table 3). $\mathrm{Kim}$ 등[9]은 LCBPPV 환자 166명 대상으로 1회 치료성공률 이 $74.1 \%$ 로 본 연구와 비교해서 약간 높은 치료성공율을 보였 다.

Chung 등[12]은 외상 후 반고리관의 변화로 인해서 이석정 복술의 횟수가 증가하였다. So 등[13]은 외상이 있는 환자와 없 는 환자를 비교했을 때 훨씬 더 외상이 있는 환자의 치료횟수가 증가한다는 이유는 외상이 평형반을 약화시켜서 이석의 발생 횟수가 증가하였다고 보고하였다. 이석정복술 시술 당일 취침 전까지 눕지 않도록 하고, 높은 베개를 사용하여 수면을 취하도 록 권장하였고, 다음 날부터 정상적인 생활을 하도록 주의를 시 켰다.

$\mathrm{Kim}$ 등[9]에 의하면 LCPBBV 환자에게 동반되어 나타나는 15 개 질환을 조사한 결과는 외상 후, 내과적 질환, 이명, 두통, 뇌 혈관 좁아짐, 뇌경색, 안뜰신경염 등 7개 인자였고, O’Reilly 등
[14]과 Baloh 등[15]도 PCBPPV에 영향을 주는 질환에 대하여 비슷하게 제시하였고, So 등[13]도 치료에 영향을 주는 인자로 외상, 중이염, 안뜰신경염을 제시하였다.

$\mathrm{PCBPPV}$ 의 이석정복술 치료횟수에 영향을 주는 인자들을 분 석해보면 1회 성공률은 원인불명이 $47.8 \%$ 로 유의적으로 가장 높았고, small vessel, 뇌경색, 안뜰신경염을 동반하면 치료율 이 현저히 떨어졌다. 그리고 3회 이상의 어지럼증이 지속된 경 우가 원인불명, 외상 후, 뇌경색, $\mathrm{VBI}$, 뇌혈관질환(척추, 뇌바닥 동맥 좁아짐 등), 안뜰신경염등이 있었다. 통계적으로 원인불 명, 외상 후, 내과적 질환, 뇌경색, 척추뇌바닥동맥기능부전증, 뇌혈관질환, 뇌질환, 안뜰신경염 등이 치료횟수와 통계학적으 로 상관성을 보였다 $(P<0.05)$ (Table 3). PCBPPV는 주로 안뜰 계와 관련된 부분의 질환에 의해 반고리관 기능의 약화로 발생 한 것으로 보인다. 뇌경색 경우 중대뇌동맥 협착으로 인해 반고 리관으로 혈류량이 감소하여 반고리관의 기능이 약화되었고, 안뜰신경염인 경우에도 평형을 담당하는 기관인 안뜰기관의 반 고리관에 염증이 동반될 수 있고, 이석치료가 되더라도 안뜰신 경염을 치료하지 않으면 계속적인 어지럼증이 지속적으로 나타 났다. 역시 Kim 등[9]에 의한 LCBPPV도 Meniere's disease(메 니에르병), 이명, 중이염, 편두통, 척추뇌바닥동맥기능부전증, 뇌혈관질환, 뇌질환, 뇌출혈을 제외하고는 양성발작성 두위현 기증과 연관된 인자와 치료횟수가 상관성이 있었다. Lee 등[16] 도 두부외상환자 9명이 모두 어지럼증을 호소하였으며, 5명이 $\mathrm{PCBPPV}$ 로 진단하였고, $\mathrm{EM}$ 으로 호전되었고 상관성을 보였다. 그러나, 이석을 유발하게 하는 Meniere's disease(메니에르병), 내림프수종(endolymphatic hydrops), 미로염(labyrinthitis) 등에 의해 PCBPPV가 유발될 경우, 치료 후에도 재발율이 높다 는 보고도 있다[17]. 본 연구와 비슷한 결과를 나타냈다. 
중추성질환을 정확히 판단하기 위하여 뇌혈관 자기공명영상 (magnetic resonance angiography, MRA)을 통해 척추뇌바 닥동맥(Veterbrobasilar artery)의 기형을 살펴본 결과 척추동 맥 또는 뇌바닥동맥의 기형에 의해 폐쇄나 협착이 생기면서 연 수에 영향을 미칠 수 있기 때문에 어지럼증과 밀접한 관련성이 있다(Figure 4, 5).

$\mathrm{PCBPPV}$ 의 $\mathrm{EM}$ 치료 횟수가 증가하는 원인은 반고리관내 이 석이 유입되게 하는 여러 인자에 의해 어지럼증이 발생한다. 이 러한 인자들에 의해 이석기관의 기능이 약화되어 평형반에서 쉽게 이석이 떨어져 나와 어지럼증이 유발되고 만약, 이러한 원 인인자가 치료되지 않으면 이석정복술에 의해 반고리관내 이석 이 제거되더라도 다시 이석이 발생하여 계속적인 어지럼증을 초래하게 될 것이다. 이런 인자들의 치료와 이석정복술을 병행 하면 치료성공 확률이 높아 질 수 있을 것이다. 뒤반고리관 양성 발작성두위현기증 외에도 본 연구에서 제시한 인자들에 의해 어지럼증이 유발될 수 도 있고, 또 이러한 인자들에 의해 뒤반고 리관 양성돌발성두위현기증이 더욱 더 악화될 수 도 있으며, 만 일 이러한 인자들이 치료가 되지 않는다면 치료횟수가 증가되 고, 계속적인 재발로 인해 삶의 질이 악화되고, 불편한 삶을 살 수 밖에 없을 것이다. 또한, 어지럼증을 호소하는 $47.8 \%$ 가 원인 불명임에도 불구하고, 반고리관내에 이석이 유입되어 어지럼 증을 호소하고 있는 점을 간과해서는 안 될 것이다. 이와같은 경 우 다른 인자들에 비해 휠씬 치료성공률은 높았다(Tables 1, 3). 비디오눈떨림 검사를 통해 가쪽반고리관, 뒤반고리관 등 이석 유입위치를 확인하여야 하고, 각각 다른 방법에 따른 치료가 요 구되고, 치료에 영향을 주는 인자들에 의하여 많은 환자들이 겪 고 있는 구토, 오심, 실신 등의 질환이 발생할 수 있지만, 양성발 작성두위현기증을 유발할 수 있는 질환 치료와 병행하고, 치료 후 주의사항을 주지시키고, 지킨다면 일상생활에 많은 불편함 과, 고통을 주는 어지럼증에서 호전될 수 있을 것이다. 만약, 양 성발작성 두위현기증 치료와상관성이 떨어지는 인자들이 존재 하고 있으면 여러 번 이석정복술을 치료를 반복하더라도, 재발 확률이 높아진다. 앞으로 평형반을 약화시킬 수 있는 여러 요인 들의 연구가 필요할 것이다.

\section{요 약}

순천성가롤로병원 어지럼증 센터에 내원한 어지럼증 환자 중 뒤반고리관 양성발작성 두위현기증은 머리나 몸을 움직일 때 갑자기 빙빙도는 느낌 또는 회전성 어지럼증을 호소하는 가 장 흔한 질환이다. 대부분 환자들은 1 회 치료로 증상이 호전된
다. 하지만, 세 번 이상 여러번 치료를 요구하는 경우도 있다. 이 석정복술에 의한 뒤반고리관 양성발작성 두위현기증환자의 어 지럼증 증상 회복에 영향을 주는 인자을 분석하였다. 어지럼증 환자 중 어지럼증 센터에 내원한 뒤반고리관 양성발작성두위현 기증 환자를 분류하였다. 2008년 3월부터 2010년 11월까지 165 명의 뒤반고리관 양성발작성두위현기증 환자 치료율을 조 사하였다. 1 회 치료성공율이 $57.6 \%, 2$ 회 치료성공율이 $17.6 \%$, 3 회 치료성공율이 $3.6 \%, 3$ 회 이상치료성공율이 $21.2 \%$ 였다. 뒤 반고리관 양성발작성두위현기증 치료에 영향을 주는 인자는 외 상 후, 내과적 질환, 뇌경색, 작은혈관 질환, 척추뇌바닥동맥기 능부전증, 뇌혈관질환, 뇌질환, 안뜰신경염이다. 위와 같은 치 료에 영향을 주는 인자들을 고려한다면 구토, 오심, 실신 등을 쉽게 치료 할 수 있을 것이다. 또한, 어지럼증 증상의 회복을 위 한 이석정복술과 연관질환을 병행 치료하면 일상생활에 많은 불편함을 주고, 고통을 주는 어지럼증에서 호전될 수 있을 것이 다. 앞으로 어지럼증을 유발하는 많은 인자들을 조사하고, 분석 할 필요가 있을 것이다.

\section{Acknowledgements: None \\ Conflict of interest: None}

\section{REFERENCES}

1. Byun JY, Ryu EW. Diagnosis and treatment of benign paroxysmal positional vertigo. Res Vestib Sci. 2010;9:55-64.

2. Lee HS, So YK. Diagnosis of vertical canal benign paroxysmal positional vertigo. J Korean Bal Soc. 2005;4:307-311.

3. Epley JM. The canalith repositioning procedure: for treatment of benign paroxysmal positional vertigo. Otolaryngol Head Neck Surg. 1992;107:399-404.

4. Rhee CK, Benign paroxysmal positional vertigo. Korean J Otolaryngol. 2004;47:491-506.

5. Jeon HG, Song SH, Han GC, Huh JM. Analysis of factors that affect the result of vestibular rehabiliation in the treatment of benign paroxysmal positional vertigo. Korean J Otolaryngol. 2001;44:1259-1263.

6. Parnes LS, Robichaud J. Further observations during the particle repositioning maneuver for benign paroxysmal positional vertigo. Otolaryngol Head Neck Surg. 1997;11.

7. Fujino A, Tokumasu K, Yosio S, Naganuma S, Yoneda S, Nakayama K. Vestibular training for benign paroxysmal positional vertigo. its efficacy in comparison with antivertigo drugs. Arch Otolaryngol Head Neck Surg. 1994;120:497-504.

8. Dix MR, Hallpike CS. The pathology, symptomatology and diagnosis of certain common disorders of the vestibular system. Ann Otol Rhinol Laryngol. 1952;61:987-1016.

9. Kim CS, Choi HY, Kwon PS, Lee EP, Seo CW. Factor analysis affecting lateral canal benign paroxysmal positional vertigo. 
Korean J Clin Lab Sci. 2015;47:35-38. https://doi.org/ 10.15324/kjcls.2015;47.1.35.

10. Furman JM, Cass SP. Benign paroxysmal positional vertigo. N Engl J Med. 1999;341:1590-1596.

11. Macias JD, Lambert KM, Massingale S, Ellensohn A, Fritz JA. Variables affecting treatment in benign paroxysmal positional vertigo. Laryngoscope. 2000;110:1921-1924.

12. Chung WH. Lee HS, So YK. Diagnosis of vertical canal benign paroxymal positional vertigo. J Korean Bal Soc. 2005;4: 307-308.

13. So YK, Chung WH, Boo SH, Chung YJ, Lee HS, Lee WY, et al. Factors affecting treatment of benign paroxysmal positional vertigo. J Korean Bal Soc. 2005;4:230-237.

14. O'Reilly RC, Elford B, Slater R. Effectiveness of the particle re- positioning maneuver in subtypes of benign paroxysmal positional vertigo. Laryngoscope. 2000;110:1385-1388.

15. Baloh RW, Honrubia, V, Jacobson, K. Benign positional vertigo: clinical and oculographic features in 240 cases. Neurology. 1987;37:371-378.

16. Lee CL, Park KH. Clinical features of patients with labyrinthine concussion after head trauma. Soonchunhyang Med Sci. 2017;23:108-111. https://doi.org/10.15746/sms.17.026.

17. Hoseinabadi R, Pourbakht A, Yazdani N, Kouhi A, Kamali M, Abdollahi FZ, et al. The effects of the vestibular rehabilitation on the benign paroxysmal positional vertigo recurrence rate in patients with otolith dysfunction. J Audiol Otol. 2018. Jul 19. [Epub ahead of print]. https://doi.org/10.7874/jao.2018.00087. 